\title{
How schools contribute to keeping students on track: Narratives from vulnerable students in vocational education and training
}

\author{
Evi Schmid, Beate Jørstad \& Gøril Stokke Nordlie
}

Oslo Metropolitan University, Norway (evi.schmid@oslomet.no)

\begin{abstract}
This article examines characteristics, practices and conditions within schools that enable vulnerable students to succeed in school. Research suggests that factors related to structure, educational organisation or the climate within schools may play a part in either pushing out or holding on to students whose personal characteristics may put them at risk of dropping out. The study is based on 25 qualitative interviews with students in the second year of vocational education and training. All the students had a low grade point average from lower secondary school, and the majority had an immigrant background from Africa or Asia. The analysis shows that practice-oriented learning from authentic work tasks provided meaningful connections between schoolwork and students' career choices and opportunities to experience success and mastery. Furthermore, positive expectations and the active support of teachers as well as mutual motivation and support among classmates contributed to students' sense of belonging at school. The study discusses the importance of schools supporting less school-oriented young people in connecting and identifying with school, both with the social environment and with the educational content and learning methods.
\end{abstract}

Keywords: vocational education and training, vocational schools, dropout, vulnerable students, school organisation 


\section{Introduction}

In many Western countries, dropout from upper secondary education is an important political issue, which has also been prioritised in EU policy following the adoption of the Lisbon Strategy in 2000. Young people who do not complete upper secondary education face serious negative economic and psychosocial consequences, which not only generate personal but also societal costs (Cedefop, 2016; Falch et al., 2009). Most of the research on dropout has focused on the factors that may be associated with dropping out and thus increase the probability of young people leaving school before time. The studies suggest that dropping out of school is the cumulative result of multiple risk factors and emphasise the interrelated effects of various levels of influence, including the family, school, educational system, and broader economic and political context (Alexander et al., 2001; Lamb, 2011; Rumberger, 2011).

This study focuses on the school level and the role of schools in preventing dropout from upper secondary education. So far, individual and family background factors have received by far the most attention, highlighting the students' school performances and their socioeconomic background among the most important factors influencing early leaving from school. Family background has a significant impact on school performance and helps to explain systematic differences in educational achievement and dropout (e.g. Lamb, 2011; Rumberger, 2011). However, studies addressing different levels of influence also emphasise the importance of the school level and indicate that the characteristics of and conditions within schools may promote or reduce dropout behaviour (Christle et al., 2007; Doll et al., 2013; Lee \& Burkam, 2003; Rumberger, 1995). Through their organisation, schools may either push out or hold on to students whose personal characteristics may put them at risk of dropping out. In research literature, conditions or situations within the school environment that affect the students' engagement with school and ultimately result in dropout, are referred to as 'push factors', distinguished from 'pull factors' outside school (Bradley \& Renzulli, 2011; Doll et al., 2013; Gambetta, 1987; Stearns \& Glennie, 2006). Hence, push factors relate to structures, practices or conditions within the school itself that lead to students viewing school as an unpleasant place and to withdrawal, disengagement, and eventually dropout - voluntarily or forced by school and its policies (e.g. Rumberger \& Thomas, 2000).

This study explores school-related factors that affect the students' engagement and identification with school. However, the focus is not on conditions or practices within schools that may contribute to pushing students out of school. This article seeks to contribute to the existing literature by exploring school-related factors that may contribute to keeping the students on track - despite the existence of some form of disadvantage. The article draws on semi-structured interviews with 25 vocational students who represent a particularly vulnerable group 
in several ways. Firstly, all the students in the study had a grade point average (GPA) below a critical level, which statistically puts them at risk of not completing upper secondary education (Kunnskapsdepartementet, 2018). Secondly, most of the students had a migration background and spoke a language other than Norwegian at home. Thirdly, most students' parents were in manual or unskilled occupations or received social benefits. Based on the research literature on dropout, these characteristics define the students in the study as being among the most vulnerable students in upper secondary education (Markussen et al., 2011; Rumberger, 2011).

Nevertheless, at the time of the interviews, the students were in the second year of their education and had successfully passed the examinations at the end of the first year. The study thus examines what makes students who belong to a risk group with respect to upper secondary graduation stay on track. The aim of this article is to obtain knowledge about the students' experiences, perceptions and feelings towards school and education and to identify characteristics of the school structure, environment, climate, instruction or learning processes that enable them to succeed in school. Consequently, the article addresses the following research question: Which characteristics, practices or conditions related to school and education do vulnerable students in upper secondary vocational education and training highlight in their narratives to explain what helps them stay on track in their education?

The study is situated in Norway, more specifically, in the capital city Oslo. The national VET system is designed according to a $2+2$ model, whereby it is organised as two years of school-based learning followed by two years of apprenticeship training. Following the normal progression, the students in the sample had about half a year of schooling ahead of them before they were due to start apprenticeships in companies. As this study is part of a longitudinal project on vulnerable youths' pathways through VET, the same group of young people will be interviewed again during the second part of their education in a training company. This article focuses on the first part of their education.

\section{The school perspective on dropping out}

Despite a preponderance of dropout research focusing on the personal characteristics of individual students, research has clearly documented that students' learning and achievement are also affected by the characteristics of the schools the students attend. Internal school factors may cover different dimensions of school organisation. Lee and Burkam (2003) propose to conceptualise the organisation of schools along the dimensions of school structure, academic organisation, and social organisation.

Structural characteristics of schools such as school location, size and resources have all been found to be related to student achievement and school dropout. A prominent issue in school effectiveness research concerns school size. Students 
in large schools are found to learn less than students in medium-sized schools (Lee \& Smith, 1997) and to be more likely to leave school before graduation (Rumberger, 1995). However, a causal link between school size and student achievement can be questioned. Rather, the results indicate that school size may act as a facilitating or debilitating factor for other organisational forms or practices that, in turn, promote student learning (Lee \& Smith, 1997). Another widely debated issue with respect to structural features of schools concerns the effect of student composition, often related to school location, on student learning and school dropout. Research shows that a high concentration of immigrant students at school may be associated with poorer student performance and higher dropout (Rumberger, 1995; Traag \& van der Velden, 2011). Yet, research from Norway shows that the relationship between the proportion of minority students at school and educational achievement or upper-secondary completion largely reflects the between-school differences in students' socioeconomic backgrounds (Hardoy et al., 2018; Hermansen \& Birkelund, 2015). Thus, differences in achievement among schools based on structural characteristics are often related to differences in students' characteristics and school resources that are often associated with the structural features of schools (see also Rumberger \& Thomas, 2000).

The academic or educational organisation of schools refers, among other characteristics, to the structure and content of the curriculum. If students perceive the educational curriculum as valuable and relevant to their interests and needs, and feel a connection between schoolwork and their lives, they are more likely to participate and engage in class work (Crumpton \& Gregory, 2011; Finn, 1989; Tinto, 2017). In fact, the perceived fit with the educational programme is found to be the most important predictor of students' sense of belonging and valuing of their education (Elffers et al., 2012). This also implies that learning goals are perceived as accessible, neither too easy nor too difficult to master, and different programmes, curricula or learning goals may be required for different groups of students. Moreover, perceptions of the quality and relevance of the curriculum also refer to the values underlying the curriculum and reflect a complex interplay of different issues including teaching methods and learning preferences (Tinto, 2017). In addition, the educational organisation of schools includes school leadership and management and associated characteristics such as rules, practices, and policies within schools. Rules or policies, for example on how to handle absenteeism, misbehaviour, or low grades, may lead to suspensions or expulsions and may thus be used as a measure to force a student out of school (Bradley \& Renzulli, 2011; see also Domina et al., 2017). Studies suggest that males and ethnic minority students are more likely than females and majority students to leave school due to suspension or expulsions (Doll et al., 2013; Rumberger, 1987).

The social organisation of schools covers aspects of school and class climate, the quality of student-teacher relations, relationships among students and social support. Both Finn (1989) and Tinto (1993) highlight the importance of the students' 
emotional connection to school, teachers, classmates, and schoolwork in their dropout process models. The feeling of being a member of a community results in a commitment that binds the student to the group or community, also referred to as 'emotional engagement' (Fredricks et al., 2004) or 'sense of belonging' (Finn, 1989; Tinto, 2017). By contrast, a student's emotional disengagement or sense of not belonging leads to withdrawal from contact and is found to be an important factor that places students at risk of dropping out, although they are performing well at school (Blondal \& Adalbjarnardottir, 2012). The importance of positive relationships at school refers in particular to peers and classmates, who are found to be a major source of students' emotional engagement with school (Elffers et al., 2012). The experience of loneliness, by contrast, is one of the most important explanations for students' intention to leave upper secondary education (Haugan et al., 2019).

In addition, the importance of positive student-teacher relationships is well documented in student engagement and dropout literature. Students who experience a close and supportive relationship with teachers and feel that teachers care about them show higher levels of engagement and identification with school and are less likely to drop out of school (Croninger \& Lee, 2001; Dunn et al., 2004; Lee \& Burkam, 2003; Wang \& Eccles, 2012). In contrast, a low level of perceived teacher support is associated with loss of interest in school (Haugan et al., 2019; Krane et al., 2017). Positive student-teacher relationships also include the teachers having positive expectations of the students' learning and performance and believing in the students' ability to succeed. Positive teacher expectations are important for the students' development at school and are associated with higher levels of motivation and student performance (Gilliam, 2018; Rosenthal \& Jacobson, 1968). Negative expectations, by contrast, may lead to withdrawal from school and complicate student-teacher relationships (Gilliam, 2018; Krane et al., 2016). A recent literature review concludes that there is relatively strong and consistent evidence in research showing that teachers have lower expectations of students from low socioeconomic backgrounds, and most studies also found lower teacher expectations of ethnic minority groups (Wang et al., 2018).

\section{Method}

\section{Background of the study and study design}

The study was carried out in Oslo, Norway, and is part of a longitudinal project on vulnerable youths' pathways through upper secondary VET. The project examines why some students succeed in school, despite some form of disadvantage, and how the students explain what it takes for them to be able to complete their education (see also Schmid, 2021; Schmid \& Garrels, 2021). The students were selected based on their grade point average (GPA) at the end of 
compulsory school (10 ${ }^{\text {th }}$ grade). In line with international research, research in Norway has identified poor educational outcomes as one of the strongest predictors of dropout from upper secondary education (Dæhlen, 2017; Markussen et al., 2011). More specifically, a recent evaluation shows that students with a GPA lower than 3.5 are at particular risk of not completing upper secondary education (Kunnskapsdepartementet, 2018). GPA is the average of all grades from the last year of lower secondary school. Grade scores range from 1 to 6 , and a minimum of 2 is needed to pass a subject. The GPA is used as the basis for admission to upper secondary education. For the school year 2018/2019, the mean GPA in Norway was 4.2 and 4.3 in the county of Oslo (Norwegian Directorate for Education and Training, 2020). However, in Oslo county, 15.6 per cent of the students leave compulsory school with a GPA lower than 3.5, and this proportion is significantly higher among male students than their female counterparts $(20.5 \%$ and $10.4 \%$ respectively) (Statistics Norway, 2020a). Less than half of the students in this group complete upper secondary education within five years $(47.6 \%)$ - compared to 90 per cent of students with a GPA higher than 3.5 (Statistics Norway, 2020b).

Since grades at school are strongly correlated with parents' educational background (Statistics Norway, 2021), selecting students by their grades implies, to a great extent, a selection based on socioeconomic background. Therefore, what further characterises the students in the sample, is their vulnerability also in terms of family resources. Most students' parents were in manual or unskilled occupations (e.g. working as cleaners or taxi drivers), unemployed or receiving social benefits. Some of the parents attended a Norwegian language course.

In addition, we limited the selection of interviewees to students in the second year of VET who had successfully passed the examinations at the end of the first year at school. Many students face educational challenges already in their first year of VET, and a significant number of students drop out before or in the course of the second year (Kunnskapsdepartementet, 2018). Thus, the students in the sample had already completed a considerable part of their education. Following the normal progression, they had about half a year of schooling ahead of them before they were due to start apprenticeships in companies.

To identify low-achieving students in upper secondary VET, we contacted four schools in Oslo where the GPA for admission to upper secondary education is comparatively low. The aim was to recruit students from different schools, classes, and educational programmes and to ensure gender variation. Twentyfive students (10 girls, 15 boys) from four different schools, eight different classes and seven different educational programmes in year 2 (childcare and youth work; construction techniques; floral design; food and beverages; health work; motor vehicles; and sales, service, and security) consented to participate. Twenty of the students were born in Norway, however, eighteen of the interviewees had a migration background: 14 were children of immigrants, most of them from 
countries in Africa or Asia (e.g. Pakistan or Somalia), and four students came to Norway between the age of 13 and 16, from either Somalia or Eritrea. Seven students were of Norwegian background. The majority of the interviewees spoke a language other than Norwegian at home. Most of the informants were 17 years old at the time of the interview and had not dropped out of education and training previously. The mean GPA in the study sample was 2.8 , and all students had a GPA below 3.5.

\section{Data collection and ethical considerations}

All the interviews were conducted by the authors between October 2019 and January 2020 at the students' schools, and they had an average duration of 30 minutes. The students were interviewed individually. A semi-structured interview guide was used to provide a framework for the interviews, with questions about enjoying school, challenges at school, thoughts about leaving school or plans to complete upper secondary education, relationships and support both within and outside school, career choice and aspirations. The interviews further included the occupation/employment status of the students' parents, the students' leisure activities, and who they lived with.

All participants received written and oral information about the project and that participation was voluntary. All students gave their written consent to participate. The Norwegian Centre for Research Data (NSD) approved this study, and we complied with the requirements of data protection legislation. Furthermore, since the students in the study may have experienced many setbacks and failures throughout their school career, we were careful not to refer to participants as 'at-risk students'. Instead, the students were informed that we were interested in their explanations for 'making it' at school. This positive approach to the study and to our informants may have contributed to the students' eagerness to share their experiences with us.

\section{Data analysis}

All interviews were recorded and transcribed verbatim. Personal information was anonymised, and all interviewees were given pseudonyms. In order to be as open-minded towards the students' narratives as possible (cf. Gibbs, 2018), the first analysis step consisted of a data driven construction of codes using the software NVivo 12. Codes were generated by identifying text fragments that contained information about the students' present situation at school. In the next step, similar codes were organised into categories that were considered purposeful with regard to the research question (Gibbs, 2018). During these steps, all authors worked together and discussed how to organise the categories. In the last step, the categories were labelled to concisely capture the essence of each category. The authors worked together to define the following four categories: 1) 
Directed towards a concrete goal, 2) Practice-oriented learning, 3) Positive and supportive relationships with teachers, and 4) Belonging in class.

\section{Findings}

In the following sections, we present the four categories we identified through our analysis, contextualised with reference to the literature. We start by presenting the categories related to the dimension of academic organisation of schools (i.e. directed towards a concrete goal, and practice-oriented learning), before reporting on the two categories related to the dimension of social organisation of schools (positive and supportive relationships with teachers, and belonging in class). We did not identify any themes within the dimension of structural characteristics of schools. All quotations are translated, and all names are pseudonyms.

\section{Directed towards a concrete goal}

Most of the students in the study got a place in the VET programme they had opted for - despite low grades in lower secondary school. Thus, the students expressed that they were learning things that they were really interested in and that were important to them and their future career. All the interviewees stated that they enjoyed school, and typical explanations for this are exemplified by Denis and Johan: 'I'm working on what I like, car mechanics. I'm pretty interested in cars, so it's fun.' 'I really like ... vocational education ... we do a lot of fun stuff, especially in floristry.' These statements testify to the students' interest in a particular occupation or field of work but also to the possibility of working towards a specific profession. This seems to create a sense of meaning and relevance, as expressed by Samuel, who explained that 'it feels less basic' at upper secondary than at lower secondary school. He further clarified:

And it's like, now you're working towards something concrete, while at lower secondary school you never really knew what you were learning for, you just went along with it. But now [...] I know that I can meet a goal.

Similarly, Sara stated why she was motivated to learn:

It's not like I just cram, and then do the test and then forget everything afterwards. Like for example things I learned last year, I still remember them, and they're things I'm going to continue to need in life.

Newmann et al. (1992, p. 23) call the kind of tasks the students referred to 'authentic work' describing tasks with a connection to the 'real world' outside school and with value and meaning beyond the instructional context. Characteristically, authentic work entails extrinsic rewards, meets intrinsic interests, and offers students a sense of ownership (Newmann et al., 1992). As some students described, the experience of a clear connection to the workplace and the world outside 
How schools contribute to keeping students on track

school may not be limited to vocational subjects but may include common core subjects such as English or Norwegian. This is exemplified by Denis:

Norwegian was not my favourite subject at lower secondary school. But now when I have Norwegian, it's not the same. If we are going to have a presentation in Norwegian, I get to talk about cars, or at least something car-related, like a car I like, and then I can present that car, and what's good about it and stuff. So it's like still Norwegian, but also trade-related.

What Denis described is called 'vocationalisation of common core subjects' and used as a strategy to create more coherence between vocational and common core subjects. It implies that the learning content, learning methods and vocabulary used in common core subjects are supposed, to a great extent, to be relevant for the practice in the chosen educational programme or profession (Repstad, 2020). As Denis clearly expressed, this approach to learning Norwegian not only increased his motivation but also changed his view of Norwegian as a subject.

\section{Practice-oriented learning}

Closely related to the students' statements about authentic work tasks is the narrative related by some of our informants about the significance of practice-oriented learning in VET. As described by Tinto (2017), perceptions of the quality and relevance of the curriculum also include teaching methods and learning style preferences. Many of the students in the study explained that they liked the practice-oriented approach to learning at school. Anne said: 'We get to work a lot with our hands, I like that. It's much better.' Moreover, through practice-oriented learning, the students experienced a sense of success and mastery that many of them hardly knew. Denis related the following:

That's my strong side, working with my hands. Writing and stuff, that's not my strength, I like working with practical things. [...] It's like, I'm much better at screwing in a screw than I am at doing maths.

Similarly, Johan described what working and learning in practice at school was like for him:

I think it's fun, and of course I enjoy being successful at something, because that's a feeling I haven't had so much before.

For most of the students in the study, primary and lower secondary school was characterised by many experiences of school failure and low mastery. As described by our informants, a different approach to learning in VET contributed to a shift towards motivation and higher self-efficacy. Practice-oriented learning environments provided opportunities for developing and demonstrating skills different to classroom teaching, offered opportunities to experience a sense of accomplishment and thus fostered self-efficacy. Self-efficacy, or a person's belief in their ability to succeed in a specific situation or at a specific task, is essential to 
student motivation and persistence (Bandura, 1997). For many students, the practical parts of their education may even have been crucial to making it at school, as expressed by Emil. Emil had struggled with concentration already in his early school years and was subsequently diagnosed with ADHD. After a turbulent time at lower secondary school with many social and familiar challenges, he had difficulty choosing a career. At the time of the interview, he was determined to become a carpenter:

It's really the case that when we're out in the workshop, that's when I work best.

And I don't even stop once until we have a break. [...] and he [the teacher] likes

that I'm motivated to work, and to work well. So that's the one thing that saves my grades.

Like Emil, the practical work in the outdoor area or the school workshop was the part of their education many students enjoyed most. Furthermore, some of them made reference to the practical training periods in companies in the subject 'vocational specialisation', which accounts for about a quarter of the teaching workload in the second year of VET. 'Vocational specialisation' may be organised differently from school to school, for example in the form of two practical training periods in companies during the second year lasting several weeks each, as described by Oskar: 'And of course we go on practical training twice [...] so that helps a bit.' Hence, these training periods may be particularly important anchor points for 'school-weary' students, as Oskar described himself, helping them to maintain motivation.

\section{Positive and supportive relationships with teachers}

Relationships and social support at school were a major issue during the interviews. Due to low grades in lower secondary school, many students did not get a place at the school of their choice. Nonetheless, the students seemed to have found their feet, saying that they were happy to be where they were, and they expressed in many ways that they enjoyed school and were experiencing positive relationships and support. This included their teachers, but also other staff at school such as social education workers, and many students described how they had helped them with different matters, conflicts, worries or private challenges. Nina summarised what several of our informants had experienced: 'If you need help, they're there.' Together, all these people seemed to create a climate that helped the students to feel comfortable and to learn. However, when it came to learning, the students mostly referred to their teachers. All the students said that they had a good relationship with their teachers, which, for many of them, was primarily related to the teachers' helpfulness. This is exemplified by Olav, who stated the following when asked whether he had a good relationship with his teachers: 
How schools contribute to keeping students on track
Olav:
Actually, I have a very good relationship with some of the teachers
Researcher: here.
Olav:
Can you explain why?
Researcher:
I guess it's just how teachers are, it's like they want us to have a good relationship.
Olav:
How do you notice that?
It's easy to notice. They try to help us, they try to find the best way to help us.

In literature, teacher support is often conceptualised as emotional support, i.e. the feeling of being valued, cared for, and respected as people, and professional support, i.e. subject-related or practical guidance and assistance. However, research shows that both dimensions of teacher support are intertwined, suggesting that students do not differentiate between different forms of support from their teachers. Rather, students may experience their teachers as either supportive or non-supportive (Haugan et al., 2019; Krane et al., 2017). This highlights the importance of support and care from teachers for positive and close studentteacher relationships, as also shown in our findings. The students in our study particularly emphasised the significance of motivation and encouragement from their teachers, as expressed by Johan:

He [contact teacher] is really good at motivating me and like pushing when it's needed, so I'm not just sitting there thinking 'I can't do this'...'yeah, yeah, yeah', like that.

Similar to Johan, other students stated that the teachers motivated and 'pushed' them to work hard and give it everything, and several students explained that their teachers' expectations of them were an important motivating factor. Jenny said: 'They somehow motivate me to want better grades and to do better.' Through their teachers' expectations, the students felt that the teachers believed in them and their ability to achieve. At the same time, the students experienced that their teachers provided the help they needed to be able to meet their goals. Common answers to the questions about what helped them to succeed in school were: 'I received a lot of support from my teachers, really a lot of support' (Samuel), or 'Obviously, the teachers gave me a lot of support' (William). The students expressed that the teachers wanted the best for them and were doing everything to help them to complete their education, and many explained that the support they got from their teachers was crucial to them being able to learn, staying motivated and to eventually complete their education.

\section{Belonging in class}

Besides the relationships with their teachers, the students highlighted the importance of having friends at school. Some of the informants referred to the school climate in general and described a climate of inclusion and acceptance, as exemplified by Emma: 'It's a nice environment and everyone has someone to hang out with at school. No haters.' However, most students spoke most about 
the class climate and classmates. They explained in different ways how classmates affected their motivation and learning. In particular, many students stated that classmates and friends at school were a major motivation for going to school. This was expressed by Anne, who answered the question about what made her succeed at school as follows:

\begin{tabular}{|c|c|}
\hline Anne: & $\begin{array}{l}\text { Friends are very important. It's like you're really more at school } \\
\text { because of your friends than because of the schoolwork itself. }\end{array}$ \\
\hline Researcher: & Friends at school? \\
\hline Anne: & $\begin{array}{l}\text { Yeah, because when I come in, they say 'Hello! Welcome!', and } \\
\text { that's very nice. You really look forward to meeting them. It's like } \\
\text { it's a reason for going to school. If they hadn't been there, then I'd } \\
\text { probably be at home a whole lot more [smiling]. }\end{array}$ \\
\hline
\end{tabular}

As described in the literature (cf. Finn, 1989; Fredricks et al., 2004; Tinto, 2017), students' emotional connection to other people at school results in a commitment, which serves to bind the student to the community even in the face of challenges. Thus, students' sense of belonging is closely associated with motivation and persistence, as also expressed by some of our informants: 'I think that friends motivate you a lot. And so you feel that you belong' (Ida). The students described how they learned together, how they supported and motivated each other, particularly in times of low motivation. Sara, who went to the same class as her best friend who had the same career goal, related the following:

We work together towards it. I motivate her when she's down, and she motivates me when I'm down.

Some students reported how they received help from their classmates when they did not understand something, others described how they stopped each other from skipping school when someone was tempted to go home or how they called each other if one of them was absent or late. Nina explained:

It's so motivating. It's like, we call each other in the morning and say: 'Make sure you come to school!' That's how important they are.

Most students mentioned the class climate and classmates when asked about why they 'had made it' that far, and some students even explained that classmates and friends at school were an important reason for not leaving school. Clearly, the feeling of being a member of a community with other students, feeling that they mattered and belonged, contributed to engagement with school and was crucial for the students' succeeding in school.

\section{Discussion}

This article has examined school-related characteristics, practices, or conditions that vulnerable students in VET highlight in their narratives about school and 
education to explain what makes them succeed in school. For the students in this study, both their educational history, characterised by setbacks, low motivation and low self-efficacy, and their family background indicate that limited educational resources were available to them. Yet, at the time of the interviews, all our informants were enrolled in their second school year, with every intention of completing their education. The findings reveal different characteristics and practices related to school and education that promoted the students' engagement with school and helped them to succeed in school. These can be summarised in two main points: 1 ) practice-oriented learning on authentic work tasks, and 2) relationships and social support.

Firstly, authentic work tasks with a connection to the world outside school fostered a sense of meaning and relevance for the students. They had the opportunity to occupy themselves with something they were interested in, that was aimed at reaching a concrete goal and that was, therefore, considered meaningful, valuable, and worthy of their effort. Moreover, the practice-oriented approach to learning linked to these kinds of work tasks offered opportunities to experience success and thus fostered the students' self-efficacy. These findings are in line with research showing that increasing the relevance of schoolwork may help to disrupt disengagement and increase the motivation of students with a history of low achievement in particular (Crumpton \& Gregory, 2011). Furthermore, as emphasised by Tinto (2017, p. 262), students' sense of belonging in school also reflects their sense of their 'academic belonging'. This refers to the students' perception of the usefulness and relevance of their education for their career goals as well as the opportunities to experience success and mastery.

Secondly, the findings emphasise the importance of close and supportive relationships in school. For one thing, this applies to teachers who played a crucial role for the students in helping them to succeed in school. Teachers' expectations of students' performance motivated them to work hard and believe in themselves and their abilities. This finding might be particularly important given the research showing that teachers have lower expectations of students from low socioeconomic backgrounds and of students from ethnic minorities (cf. Wang et al., 2018). At the same time, the students' experience of receiving a lot of support from their teachers is a recurring finding in the students' narratives. The findings thus indicate that the teachers had a proactive role in supporting the students, thus corroborating the importance of teachers actively reaching out to at-risk students to enable them to capitalise on the resources and support available in school (cf. Elffers, 2013). In addition, research suggests that this type of social capital is particularly favourable to students with a history of school-related difficulties (Croninger \& Lee, 2001), further highlighting the importance of teachers' taking an active role in supporting vulnerable students.

In addition, classmates, often called friends, played a major role in enhancing students' emotional connection to school. Close relationships to classmates 
contributed to the students' sense of being part of a community, being valued and appreciated. The students described in many ways how classmates and friends were a major motivation for going to school and for doing schoolwork. Moreover, the students' narratives testify to a group of young people with a lot of empathy for each other and who tried to support each other. Clearly, our findings show how a sense of membership or belonging (Newmann et al., 1992; Tinto, 1993) can act as a driving force and contribute to engagement with school.

In this study, we chose to have a positive approach to the processes that may lead to dropout from upper secondary education. Unlike most other studies in the field, we did not focus on factors within schools that contribute to pushing students out of school, but on characteristics, practices and conditions within schools that contribute to students' succeeding in school and that help them to stay on track. Hence, in this article, we did not discuss school-related practices or conditions that the students may have experienced as challenging or difficult. However, it is important to mention that the students in our study were all predominantly positive in their narratives about school, learning and instruction and the relationships they experienced at school. Although many of them were experiencing periods of low motivation and some of them also admitted to thinking about leaving school from time to time, all the students were determined to complete upper secondary education.

\section{Conclusion}

Schools are obligated to create an environment in which young people from all backgrounds and abilities can experience success and develop aspirations for a future career. However, many schools fail in particular to support less schooloriented young people from lower socioeconomic backgrounds in connecting and identifying with school. Our findings show that schools play a crucial role in preventing dropout from upper secondary education. Although students enter upper secondary education with different backgrounds and different educational experiences, some of them better equipped and prepared to succeed than others, it is their experiences in school that ultimately shape their persistence, their aspirations, and their commitments. Through their organisation and internal practices, schools may significantly impact students' sense of belonging in school, both in terms of their connection to the social environment and their connection to the educational content and learning methods. As our findings show, this also includes students with a history of school-related difficulties and low previous connection to school, like the students in our study. The study concludes that teachers play a key role. In particular, we highlight the importance of teachers discussing meaningful connections between schoolwork and students' lives and career choices together with the students. Furthermore, the findings point to the significance of educational expectations, encouragement, and pressure to 
achieve. At the same time, teachers should take an active role in supporting vulnerable students. Finally, we emphasise the role teachers play in developing the classroom climate and students' relationships in the classroom.

The students in our study represent a hard-to-reach group for researchers and policy makers. Through qualitative interviews, they were given a voice. Hence, the findings from this study contribute to the field by providing insights from their perspective and by presenting the students' personal narratives.

\section{Notes on contributors}

Evi Schmid, PhD, is an associate professor at the Department of Vocational Teacher Education at OsloMet - Oslo Metropolitan University, Norway. Her current research interests include school-to-work transitions, dropout from VET, learning environments, and alternative training pathways.

Beate Jørstad is a vocational teacher and student in the Master's programme in Vocational pedagogy at OsloMet - Oslo Metropolitan University. Her research interests are dropout, self-efficacy, and guidance of students with special needs.

Gøril Stokke Nordlie is a vocational teacher and student in the Master's programme in Vocational pedagogy at OsloMet - Oslo Metropolitan University. She is interested in research on dropout, school refusal, school climate, and relationships at school. 


\section{References}

Alexander, K. L., Entwisle, D. R., \& Kabbani, N. (2001). The dropout process in life course perspective: Early risk factors at home and school. Teachers College Record, 103(5), 760-822. https://doi.org/10.1111/0161-4681.00134

Bandura, A. (1997). Self-efficacy: The exercise of control. Freeman.

Blondal, K. S., \& Adalbjarnardottir, S. (2012). Student disengagement in relation to expected and unexpected educational pathways. Scandinavian Journal of Educational Research, 56(1), 85-100.

https:// doi.org/10.1080/00313831.2011.568607

Bradley, C. L., \& Renzulli, L. A. (2011). The complexity of non-completion: Being pushed or pulled to drop out of high school. Social Forces, 90(2), 521-545. https://doi.org/10.1093/sf/sor003

Cedefop. (2016). Leaving education early: Putting vocational education and training centre stage. Volume I: Investigating causes and extent. Publications Office of the European Union.

Christle, C. A., Jolivette, K., \& Nelson, C. M. (2007). School characteristics related to high school dropout rates. Remedial and Special Education, 28(6), 325-339. https://doi.org/10.1177/07419325070280060201

Croninger, R. G., \& Lee, V. E. (2001). Social capital and dropping out of high school: Benefits to at-risk students of teachers' support and guidance. Teachers College Record, 103(4), 548-581. https:/ / doi.org/10.1111/0161-4681.00127

Crumpton, H. E., \& Gregory, A. (2011). "I'm not learning": The role of academic relevancy for low-achieving students. The Journal of Educational Research, 104(1), 42-53. https:/ / doi.org/10.1080/00220670903567398

Doll, J. J., Eslami, Z., \& Walters, L. (2013). Understanding why students drop out of high school, according to their own reports: Are they pushed or pulled, or do they fall out? A comparative analysis of seven nationally representative studies. SAGE Open, 3(4), 1-15. https://doi.org/10.1177/2158244013503834

Domina, T., Penner, A., \& Penner, E. (2017). Categorical inequality: Schools as sorting machines. Annual Review of Sociology, 43(1), 311-330. https:// doi.org/10.1146/annurev-soc-060116-053354

Dunn, C., Chambers, D., \& Rabren, K. (2004). Variables affecting students' decisions to drop out of school. Remedial and Special Education, 25(5), 314-323. https:/ / doi.org/10.1177/07419325040250050501

Dæhlen, M. (2017). Completion in vocational and academic upper secondary school: The importance of school motivation, self-efficacy, and individual characteristics. European Journal of Education, 52(3), 336-347.

https://doi.org/10.1111/ejed.12223 
Elffers, L., Oort, F. J., \& Karsten, S. (2012). Making the connection: The role of social and academic school experiences in students' emotional engagement with school in post-secondary vocational education. Learning and Individual Differences, 22(2), 242-250. https:/ / doi.org/10.1016/j.lindif.2011.08.005

Elffers, L. (2013). Staying on track: Behavioral engagement of at-risk and non-atrisk students in post-secondary vocational education. European Journal of Psychology of Education, 28(2), 545-562. https:/ / doi.org/10.1007/s10212-012-0128-3

Falch, T., Johannesen, A. B., \& Strøm, B. (2009). Kostnader av frafall i videregående opplaring [Costs of dropout from upper secondary education]. Senter for Økonomisk Forskning.

Finn, J. D. (1989). Withdrawing from school. Review of Educational Research, 59(2), 117-142. https:// doi.org/10.3102/00346543059002117

Fredricks, J. A., Blumenfeld, P. C., \& Paris, A. H. (2004). School engagement: Potential of the concept, state of the evidence. Review of Educational Research, 74(1), 59-109. https:// doi.org/10.3102/00346543074001059

Gambetta, D. (1987). Were they pushed or did they jump? Individual decision mechanisms in education. Cambride University Press. https:/ / doi.org/10.1017/CBO9780511735868

Gibbs, G. R. (2018). Analyzing qualitative data. SAGE.

Gilliam, L. (2018). Minoritetsdanske drenge i skolen: Modvilje og forskelsbehandling [Minority Danish boys in school: Aversion and discrimination]. Aarhus universitetsforlag.

Hardoy, I., Mastekaasa, A., \& Schøne, P. (2018). Immigrant concentration and student outcomes in upper secondary schools: Norwegian evidence. European Societies, 20(2), 301-321. https://doi.org/10.1080/14616696.2017.1402120

Haugan, J. A., Frostad, P., \& Mjaavatn, P.-E. (2019). A longitudinal study of factors predicting students' intentions to leave upper secondary school in Norway. Social Psychology of Education, 22(5), 1259-1279.

https:/ / doi.org/10.1007/s11218-019-09527-0

Hermansen, A. S., \& Birkelund, G. E. (2015). The impact of immigrant classmates on educational outcomes. Social Forces, 94(2), 615-646. https://doi.org/10.1093/sf/sov073

Krane, V., Karlsson, B., Ness, O., \& Binder, P.-E. (2016). They need to be recognized as a person in everyday life: Teachers' and helpers' experiences of teacher-student relationships in upper secondary school. International Journal of Qualitative Studies on Health and Well-being, 11(1), 31634.

https:/ / doi.org/10.3402/qhw.v11.31634 
Krane, V., Ness, O., Holter-Sorensen, N., Karlsson, B., \& Binder, P.-E. (2017). 'You notice that there is something positive about going to school': How teachers' kindness can promote positive teacher-student relationships in upper secondary school. International Journal of Adolescence and Youth, 22(4), 377-389. https:/ / doi.org/10.1080/02673843.2016.1202843

Lamb, S. (2011). School dropout and inequality. In S. Lamb, E. Markussen, R. Teese, N. Sandberg, \& J. Polesel (Eds.), School dropout and completion: International comparative studies in theory and policy (pp. 369-390). Springer.

Lee, V. E., \& Burkam, D. T. (2003). Dropping out of high school: The role of school organization and structure. American Educational Research Journal, 40(2), 353393. https:// doi.org/10.3102/00028312040002353

Lee, V. E., \& Smith, J. B. (1997). High school size: Which works best and for whom? Educational Evaluation and Policy Analysis, 19(3), 205-227. https:/ / doi.org/10.3102/01623737019003205

Markussen, E., Frøseth, M. W., Sandberg, N., Lødding, B., \& Borgen, J. S. (2011). Early leaving, non-completion and completion in upper secondary education in Norway. In S. Lamb, E. Markussen, R. Teese, N. Sandberg, \& J. Polesel (Eds.), School dropout and completion: International comparative studies in theory and policy (pp. 253-271). Springer.

Newmann, F. M., Wehlage, G. G., \& Lamborn, S. D. (1992). The significance and sources of student engagement. In F. M. Newmann (Ed.), Student engagement and achievement in American secondary schools (pp. 11-39). Teachers College Press.

Norwegian Directorate for Education and Training. (2020). Grunnskolepoeng [Grade point average]. https://www.udir.no/tall-og-forskning/statistikk/statistikk-grunnskole/grunnskolepoeng/

Kunnskapsdepartementet. (2018). Kvalifisert, forberedt og motivert: Et kunnskapsgrunnlag om struktur og innhold $i$ videregående opplæring [Qualified, prepared, and motivated. A knowledge base on structure and content in upper secondary education] (Norwegian White Paper 2018:15).

Repstad, K. (2020). Yrkesretting av fellesfag (2. ed.) [Vocationalisation of common core subjects]. Pedlex.

Rosenthal, R., \& Jacobson, L. (1968). Pygmalion in the classroom. Urban Review, 3(1), 16-20. https:/ / doi.org/10.1007/BF02322211

Rumberger, R. W. (1987). High school dropouts: A review of issues and evidence. Review of Educational Research, 57(2), 101-121. https:/ / doi.org/10.3102/00346543057002101

Rumberger, R. W. (1995). Dropping out of middle school: A multilevel analysis of students and schools. American Educational Research Journal, 32(3), 583-625. https:/ / doi.org/10.3102/00028312032003583 
Rumberger, R. W. (2011). Dropping out: Why students drop out of high school and what can be done about it. Harvard University Press. https:/ / doi.org/10.4159/harvard.9780674063167

Rumberger, R. W., \& Thomas, S. L. (2000). The distribution of dropout and turnover rates among urban and suburban high schools. Sociology of Education, 73(1), 39-67. https:/ / doi.org/10.2307/2673198

Schmid, E. (2021). "Alle sammen støtter hverandre og hjelper hverandre hvis vi trenger motivasjon": Et elevperspektiv på læring og relasjoner i flerkulturelle videregående skoler med lave inntakskrav ['Everyone supports and helps each other when we need motivation': A student perspective on learning and relations in multi-ethnic upper secondary schools with low admission requirements]. Nordisk tidsskrift for ungdomsforskning, 2(1), 44-60.

https://doi.org/10.18261/issn.2535-8162-2021-01-03

Schmid, E., \& Garrels, V. (2021). Parental involvement and educational success among vulnerable students in vocational education and training. Educational Research. https:/ / doi.org/ 10.1080/00131881.2021.1988672

Statistics Norway. (2020a). Karakterer ved avsluttet grunnskole [Grades at the end of elementary school]. https://www.ssb.no/statbank/table/11688/

Statistics Norway. (2020b). Gjennomføring i videregående opplæring [Completion of upper secondary education]. https://www.ssb.no/statbank/table/11592/

Statistics Norway. (2021). Marks, lower secondary school. https:/ / www.ssb.no/en/utdanning/statistikker/kargrs/aar

Stearns, E., \& Glennie, E. J. (2006). When and why dropouts leave high school. Youth E Society, 38(1), 29-57. https://doi.org/10.1177/0044118X05282764

Tinto, V. (1993). Leaving college: Rethinking the causes and cures of student attrition. The University of Chigaco Press. https:/ / doi.org/10.7208/chicago/9780226922461.001.0001

Tinto, V. (2017). Through the eyes of students. Journal of College Student Retention: Research, Theory \& Practice, 19(3), 254-269. https:/ / doi.org/10.1177/1521025115621917

Traag, T., \& van der Velden, R. K. W. (2011). Early school-leaving in the Netherlands: The role of family resources, school composition and background characteristics in early school-leaving in lower secondary education. Irish Educational Studies, 30(1), 45-62. https://doi.org/10.1080/03323315.2011.535975

Wang, M.-T., \& Eccles, J. S. (2012). Social support matters: Longitudinal effects of social support on three dimensions of school engagement from middle to high school. Child Development, 83(3), 877-895.

https:/ / doi.org/10.1111/j.1467-8624.2012.01745.x

Wang, S., Rubie-Davies, C. M., \& Meissel, K. (2018). A systematic review of the teacher expectation literature over the past 30 years. Educational Research and Evaluation, 24(3-5), 124-179. https://doi.org/10.1080/13803611.2018.1548798 